\title{
Expression of menin gene mRNA in pituitary tumours
}

\author{
Maria Antonia Satta, Marta Korbonits, Richard A Jacobs, Daphne A Bolden-Dwinfour, Gregory A Kaltsas,
} Valeria Vangeli, Eric Adams ${ }^{1}$, Rudolf Fahlbusch ${ }^{1}$ and Ashley B Grossman

Department of Endocrinology, St Bartholomew's Hospital, London EC1A 7BE, UK and ${ }^{1}$ Neurochirurgische Klinik der Universitat Erlangen-Nurnberg, Erlangen, Germany

(Correspondence should be addressed to A B Grossman)

\begin{abstract}
Objective: Multiple endocrine neoplasia type 1 (MEN 1) is an autosomal dominant inherited disorder characterised by the combined occurrence of parathyroid, endocrine pancreas and anterior pituitary tumours. The gene responsible for MEN 1, the menin gene, a putative tumour-suppressor gene located on human chromosome 11q13, has been cloned. To investigate the role of the menin gene in sporadic anterior pituitary tumorigenesis, its mRNA was assessed in a group of pituitary tumours.

Methods: Menin gene expression, along with glyceraldehyde phosphate dehydrogenase (GAPDH) gene expression, has been studied in a group of normal pituitaries and in 23 pituitary tumours not associated with the MEN 1 syndrome. The pituitary tumours included 4 prolactinomas, 11 growthhormone-secreting tumours and 8 non-functional tumours. Total RNA was extracted from the normal pituitaries and tumours, and cDNA was synthesised with standard reverse transcriptase methods. Duplex polymerase chain reaction (PCR) was standardised in order to quantify the expression of the menin gene using intron-spanning primers across exons 9 and 10 in relation to the 'house-keeping' gene GAPDH. The PCR products were separated on agarose gel and densitometric analysis of the bands allowed semi-quantification.

Results: There was no evidence for a change in menin gene expression in any of the pituitary tumours when compared with normal pituitaries.

Conclusions: These studies complement previous work on mutational analysis, and do not suggest a major role for the menin suppressor gene in sporadic pituitary tumorigenesis.
\end{abstract}

European Journal of Endocrinology 140 358-361

\section{Introduction}

Pituitary tumours, representing some $10 \%$ of intracranial neoplasms, may be associated with clinical effects secondary to the hypersecretion of pituitary hormones and/or demonstrate local mass effects (1). It is now considered that the majority, if not all, pituitary adenomas are monoclonal, suggesting that an important step in tumour development is the mutation in a progenitor cell which has selective survival advantage $(2,3)$. However, somatic mutations involving genes currently known to be involved in the regulation of cell proliferation have not been readily identified, and the genetic aetiology of most pituitary tumours remains unknown (4).

Multiple endocrine neoplasia type 1 (MEN 1) is an autosomal dominant inherited disorder, with an approximate prevalence of 1:100000 and with 94\% penetrance by age 50 years (5). The syndrome is characterised by varying combinations of tumours of the parathyroids, endocrine pancreas and anterior pituitary; other, less commonly, associated tumours include those from thymic, bronchial and gastrointestinal neuroendocrine tissues, the adrenals, lipomas, angiofibromas, angiomyolipomas, thyroid adenomas and ependymomas. Recently, the gene responsible for the MEN 1 syndrome, the menin gene, a putative tumour-suppressor gene located on human chromosome 11q13, has been cloned. The menin gene encodes a 610-amino acid protein, menin, which appears to be predominantly located in the nucleus $(5-7)$. Menin is also involved in familial tumours of the parathyroid and endocrine pancreas (6), while somatic mutations in the menin gene have been reported in sporadic gastrinomas, insulinomas and parathyroid tumours $(8,9)$. Since pituitary tumours are a major feature of MEN 1, there has been considerable interest in the possibility that sporadic pituitary tumours may harbour somatic mutations of the menin gene. However, such mutations, if they occur at all, appear to be extremely rare $(10,11)$. Nevertheless, approximately $20 \%$ of sporadic pituitary tumours show loss of heterozygosity in the $11 \mathrm{q} 13$ 
Table 1 Oligonucleotide primers used.

\begin{tabular}{llcc}
\hline Gene & \multicolumn{1}{c}{ Sense primer } & Antisense primer & Size (bp) \\
\hline Menin & 5'-GCAAATGGGAGGAGGGCAGT-3' & 5'-GGGTCCCCACAAGCGGTCCGAA-3' $^{\prime}$ & 606 \\
GAPDH & 5'-CCATGGAGAAGGCTGGGG-3' $^{\prime}$ 5'-CAAAGTTGTCATGGATGACC-3' & 200 \\
Pit-1 & 5'-AGTGCTGCCGAGTGTCTACCA-3' $^{\prime}$ & 5'-TTTCTTTTCCTTTCATTTGCT-3' $^{\prime}$ & 560 \\
\hline
\end{tabular}

region, suggesting the possibility that underexpresssion of the menin gene may contribute significantly to pituitary tumour pathogenesis (12). Expression of the menin gene was reported as simply being present in sporadic pituitary tumours in one recent publication (11), while no evidence of under-expression was noted in a study published at the completion of the present investigation (13). Therefore, in order to elucidate the potential aetiological role of the menin gene in sporadic pituitary tumorigenesis, we studied menin gene expression semi-quantitatively in a group of sporadic pituitary tumours compared with normal human pituitary tissue.

\section{Patients and methods}

\section{Tissues}

Post-mortem normal pituitaries removed within $12 \mathrm{~h}$ of death (control group, $n=4$ ) and transsphenoidallyremoved pituitary tumours $(n=23)$ were snap-frozen and stored at $-70^{\circ} \mathrm{C}$. The pituitary tumours included those from patients with acromegaly $(n=11)$ and prolactinoma $(n=4)$, as well as a group of nonfunctional tumours (NFTs) $(n=8)$. The tumour samples were taken from the centre of the tumour specimens, which were confirmed histopathologically and immunohistochemically. All patients had undergone full endocrine and clinical evaluation and no patient showed any evidence of MEN 1. The normal pituitaries were taken from patients with no evidence of endocrine disease.

\section{Reverse transcription and duplex polymerase chain reaction (PCR)}

Total RNA was extracted from the tissues using acid guanidinium thiocyanate phenol/chloroform extraction. Extracted RNA was reverse transcribed as previously described (11). The cDNA equivalent of $0.25 \mu \mathrm{g}$ total RNA was replicated in duplex PCR reactions in a volume of $25 \mu \mathrm{l}$. The duplex PCR was made using primers for the 'house-keeping' gene glyceraldehyde phosphate dehydrogenase (GAPDH) (Genbank accession no. m33197) and primers for the menin gene (Genbank accession no. U93236) that span an intron in order to exclude contamination with genomic DNA. Primers for menin encompassed exons 9 and 10 giving rise to a product of $606 \mathrm{bp}$; genomic DNA contamination would have shown a product of $822 \mathrm{bp}$. The concentration of these primers was $0.4 \mu \mathrm{mol} / \mathrm{l}$ per reaction and are delineated in Table 1 along with their expected product size. Other PCR components including 10\% dimethyl sulphoxide were $\times 1$ Taq buffer, $2.5 \mathrm{mmol} / \mathrm{l} \mathrm{MgCl}_{2}$, $200 \mu \mathrm{M}$ dNTP (Promega, Southampton, UK) and $1.1 \mu \mathrm{g}$ Taq start antibody (Clontech, Palo Alto, CA, USA). PCR conditions were as follows: an initial cycle at $94^{\circ} \mathrm{C}$ for $3 \mathrm{~min}$, then 30 cycles, in a Hybaid OmniGene thermo-cycler, of $1 \mathrm{~min}$ at each of $95^{\circ} \mathrm{C}, 62^{\circ} \mathrm{C}$ and $72^{\circ} \mathrm{C}$ followed by $5 \mathrm{~min}$ at $72^{\circ} \mathrm{C}$. All PCR products, when amplified for 30 cycles, remained within the exponential phase of the reaction on the linear range for both menin and GAPDH gene products. Ten microlitres of the final reaction product were then run on a $2 \%$ agarose gel and viewed using UV light (312 nm) on a transilluminator. Polaroid photographs were taken and the densitometry of the resulting bands evaluated using a Bio Rad GS-670 imaging densitometer. Results were expressed as the ratio of the optical density of each PCR band for the menin gene to that of GAPDH, and this ratio was then compared with the normal autopsy samples for each histological subtype of tumour. We have previously established that there is a linear relationship between the densitometric ratio and the amount of the cDNA gene products added (14-16). Control (normal autopsy) and water blank samples were co-amplified with the tumours and run with each gel. The PCR product of the menin gene was cloned into the pCRII vector (Invitrogene, Leek, The Netherlands), transformed into competent $E$. coli then sequenced (Sequenase 2.0 kit, US Biochemicals, Cleveland, OH, USA): this confirmed sequence identity with the expected product based on the published sequence. A PCR reaction for the Pit-1 gene (Genbank accession no. D10216) was also performed in all tissues from NFTs in order to comfirm an absence of contamination with normal pituitary. This gene is expressed in normal pituitary, in prolactinomas, and in growth hormone (GH)-secreting tumours, but is not expressed in NFTs. We used previously published primers giving rise to a product of $560 \mathrm{bp}$ (17) (Table 1).

\section{Statistical analysis}

The data were analysed by means of Student's $t$-test with the Bonferroni correction for multiple comparisons, and are given as means \pm S.D.. Significance was taken as $P<0.05$. 


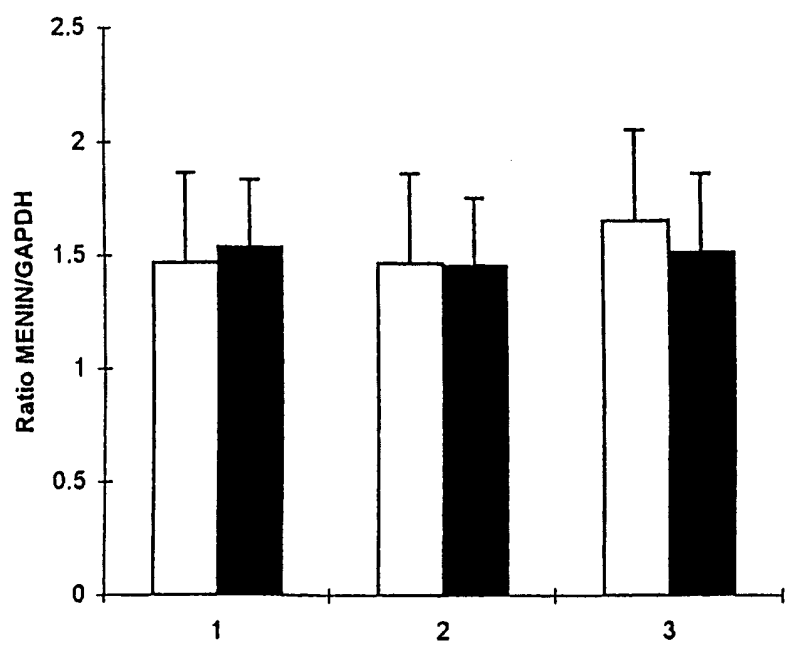

Figure 1 Relative amounts of menin and GAPDH cDNA from control pituitaries (open bars, $n=4$ ) and from (1) GH-secreting sporadic pituitary tumours (solid bars, $n=11$ ), (2) sporadic prolactinomas (solid bars, $n=4$ ) and (3) non-functional pituitary tumours (solid bars, $n=8$ ). The data represent means \pm S.D..

\section{Results}

Bands of the expected size for menin and GAPDH products were seen in all gels. Menin was uniformly expressed in all the pituitary tumours examined. Control normal pituitaries were run simultaneously with each group of pituitary tumours. Thus, the mean ratio for each group was: prolactinoma 1.46 \pm 0.3 , range 1.3-1.7 (normal control $1.47 \pm 0.4$, range $1.3-$ 1.7 ), acromegaly $1.54 \pm 0.3$, range $1.2-1.8$ (normal control 1.47 \pm 0.4 , range $1.3-1.7)$ and NFT $1.52 \pm 0.35$, range 1.3-1.9 (normal control $1.66 \pm 0.4$, range $1.4-1.9$ ) (Fig. 1). There was no significant difference between any of the groups and the normal pituitaries. Pit-1 was not expressed in the NFTs but was expressed in all other tissues studied.

\section{Discussion}

We have used a semi-quantitative assessment of mRNA in order to investigate the expression of the menin gene in relation to the house-keeping gene GAPDH in a series of pituitary tumours. Our results showed that there was no change in overall menin gene expression in pituitary tumours compared with the normal pituitary, with all tumours showing menin expression clustering around our normal range. The technique used has previously been extensively validated, and has been utilised to explore the relative expression of putative oncogenes in human corticotrophinomas (14-16). While autopsy material will undoubtedly have been processed slightly differently to surgical specimens, and inevitably with some degree of time delay, there is no reason to suspect that differential degradation of GAPDH occurs with respect to menin. The present results confirm and extend the recent reports that menin is expressed in pituitary tumours $(11,12)$ by indicating that the quantitative expression of menin is not markedly altered; this, in turn, suggests that changes in menin expression are unlikely to be involved in the pathogenesis of the majority of pituitary tumours and is concordant with another very recent publication using broadly similar methodology (13). In previous work, mutations in the menin gene were identified in $2 / 39$ sporadic tumours using SSCP analysis (10), but in 0/45 when putative mutations were sought using the more specific technique of ddF (11). This unexpected finding indicated that exonic abnormalities were only very rarely, if at all, involved in sporadic pituitary tumour formation, but left open the possibility that subtle changes in the expression of menin mRNA might still be implicated. Thus, hemi-allelic imprinting, possibly involving methylation, could still be important as a gene dosage effect. However, our findings render even this improbable, although we cannot exclude the possibility that there may be a subset of such tumours in which a significant fall in menin expression may be oncogenic. Thus, there may be a group of highly invasive or frankly malignant tumours which might show specific differences; it must also be noted that we did not investigate any corticotrophinomas, although no change in menin expression was recently reported in six such tumours (13). It may also be considered that changes in protein translation effects might occur in the absence of an alteration of mRNA expression. We have recently investigated the possible role of the tumour suppressor gene p27 in corticotrophinoma pathogenesis, and while exluding a major role for this gene or its mRNA, we noted an absence of p27 protein product, in the face of substantially normal message, in more malignant tumours (16). Nevertheless, taken together with the increasing data on mutational analysis, our findings offer no support to the speculation that the menin gene is frequently involved in sporadic tumour pathogenesis.

\section{References}

1 Greenman Y \& Melmed S. Diagnosis and management of non functioning pituitary tumours. Annual Review of Medicine 1996 47 95-106.

2 Alexander JM, Biller BM, Bikkal H, Zervas NT, Arnol A, Kibanski A et al. Clinically nonfunctioning pituitary tumours are monoclonal in origin. Journal of Clinical Investigation $1990 \mathbf{8 6}$ 336-340.

3 Herman V, Fagin J, Gonsky R, Kovacs K \& Melmed S. Clonal origin of pituitary adenomas. Journal of Clinical Endocrinology and Metabolism 199071 1427-1433.

4 Shimon I \& Melmed S. Pituitary tumour pathogenesis. Journal of Clinical Endocrinology and Metabolism 199782 1675-1681.

5 Lemmens I, Van de Ven WJ, Kas K, Zhang CX, Giraud S, Wautot V et al. Identification of the multiple endocrine neoplasia type 1 (MEN 1) gene. Human Molecular Genetics 19976 1177-1183. 
6 Chandrasekharappa SC, Guru SC, Manickam P, Olufeni SE, Collins FS, Emmert-Buck MR et al. Positional cloning of the gene for multiple endocrine neoplasia-type 1. Science 1997276 404-407.

7 Guru SC, Goldsmith PK, Burns AL, Marx SJ, Spiegel AM, Collins FS et al. Menin the product of the MEN1 gene, is a nuclear protein. Proceedings of the National Academy of Sciences of the USA 199895 $1630-1634$

8 Zhuang Z, Vortmeyer AO, Pack S, Huang S, Phan TA, Wang C et al. Somatic mutation of the MEN1 tumour suppressor gene in sporadic gastrinomas and insulinomas. Cancer Research $1997574682-4686$.

9 Heppner C, Kester MB, Agarwal SK, Debelenko LV, Emmert-Buck MR, Guru SC et al. Somatic mutation of the MEN1 gene in parathyroid tumours. Nature Genetics 199716 375-378.

10 Zhuang Z, Ezzat SZ, Vortmeyer AO, Weil R, Oldfield EH, Park WS et al. Mutation of the MEN1 tumour suppressor gene in pituitary tumours. Cancer Research 199757 5446-5451.

11 Prezant TR, Levine J \& Melmed S. Molecular characterization of the MEN1 tumour suppressor gene in sporadic pituitary tumours. Journal of Clinical Endocrinology and Metabolism 199883 1388-1391.

12 Boggild MD, Jenkinson S, Pistorello M, Boscaro M, Scanarini M, McTerman $\mathrm{P}$ et al. Molecular genetic studies of sporadic pituitary tumours. Journal of Clinical Endocrinology and Metabolism 199478 387-392.
13 Asa SL, Somers K \& Ezzat S. The MEN-1 gene is rarely downregulated in pituitary adenomas. Journal of Clinical Endocrinology and Metabolism 199883 3210-3212.

14 Dahia PLM, Ahmed-Shuaib A, Jacobs RA, Chew SL, Honeger J, Fahlbush R et al. Vasopressin receptor expression and mutation analysis in corticotropin-secreting tumours. Journal of Clinical Endocrinology and Metabolism 199681 1768-1771.

15 Dahia PML, Honegger J, Reincke M, Jacobs RA, Mirtella A, Fahlbush $\mathrm{R}$ et al. Expression of glucocorticoid receptor gene isoforms in corticotropin-secreting tumours. Journal of Clinical Endocrinology and Metabolism 199782 1088-1093.

16 Dahia PLM, Aguiar RCT, Honegger J, Fahlbush R, Jordan S, Lowe DG et al. Mutation and expression analysis of the p27/Kip 1 gene in corticotrophin-secreting tumours. Oncogene 199816 69-76.

17 Haddad G, Penabad JL, Bashey HM, Asa SL, Genarelli TA, Cirullo $\mathrm{R}$ et al. Expression of activin/inhibin subunit messenger ribonucleic acids by gonadotroph adenomas. Journal of Clinical Endocrinology and Metabolism 199479 1399-1403.

Received 14 October 1998

Accepted 18 December 1998 